\title{
Improving the Investment Policy of Countries with a Transit Economy: the Experience of Kazakhstan
}

\author{
Gulnara M. Aubakirova ${ }^{1}$, Saule K. Mazhitova ${ }^{2}$, Farida M. Isatayeva ${ }^{1 *}$, \\ Aigerim E Tomashinova² \\ ${ }^{1}$ Karaganda Technical University, Republic of Kazakhstan, 56 N. Nazarbayev Ave., 100027, \\ Karaganda, Kazakhstan \\ ${ }^{2}$ Karaganda University of Kazpotrebsoyuz, 9 Akademicheskaya, Str., 100009, Karaganda, \\ Kazakhstan
}

\begin{abstract}
The relevance of the study is determined by fact that Kazakhstan faces difficult tasks to ensure sustainable economic growth, the solution largely depends on investment policy. Since the key feature of the country's economy is a high level of technological heterogeneity, new industrial policy, implemented in the country since 2010, is designed to eliminate the technological backwardness of industries, ensure the renewal of capital, and create new points of innovation and investment growth. The purpose of the article is to identify the main problems of the investment policy of Kazakhstan, based on the analysis of its generalized indicators, and to formulate the directions for its improvement in the medium term. Following global trends, Kazakhstan is entering the stage of the fourth energy transition to the use of renewable energy sources. However, the continued dependence of the country's economy on energy leads to the fact that the decline in prices for raw materials in the world markets reduces the competitive position of mining enterprises in the world market. In light of the above and given that the field of renewable energy sources will become the most attractive investment area in the foreseeable future, the authors emphasize the importance of structural measures to improve the investment environment for attracting foreign capital and advanced technologies to the development of alternative energy. In the context of the increasing complexity of national industries, the considered experience of Kazakhstan in improving investment policy can be useful for an in-depth study of transformational transformations in countries with a transitional economy.
\end{abstract}

Keywords: transit economy, Kazakhstan, diversification, government regulation, foreign direct investment, decarbonization of the economy.

For citation: Aubakirova, G.M., Mazhitova, S.K., Isataeva, F.M., \& Tomashinova A.E. (2021). Improving the Investment Policy of Countries with a Transit Economy: the Experience of Kazakhstan. Economics: Strategy and Practice, 16(4), 46-61, https://doi.org/10.51176/1997-9967-2021-4 -46-61

* Corresponding author: Isatayeva F.M. - PhD, Karaganda Technical University, Republic of Kazakhstan, 100000, Karaganda, 34 Nurzhanova Str., Head of the Department of Geology and Exploration of Mineral Deposits, 87016064653, e-mail: adambekova_farid@mail.ru

Conflict of interest: The authors declare no conflict of interest

Financial support: The study was not sponsored (own resources)

The article received: 09.12 .2021

The article approved for publication: 29.12 .2021

Date of publication: 30.12 .2021 


\title{
Транзиттік экономикасы бар елдердің инвестициялық саясатын жетілдіру: Қазақстан тәжірибесі
}

\author{
Аубакирова Г.М. ${ }^{1}$, Мажитова С.К. ${ }^{2}$, Исатаева Ф.М. ${ }^{1 *}$, Томашинова А.Е. ${ }^{2}$ \\ ${ }^{1}$ Қараванды техникалық университеті, Қазақ̧стан Республикасы, Н.Назарбаев даңзв., 56, \\ 100027, Қараванды, Қазақстан \\ ${ }^{2}$ Қараванды Қазтұтынуодавы университеті, Академическая к., 9, 100009, Қараванды, \\ Қазақстан Республикасы
}

\section{Түйін}

Зерттеудің өзектілігі Қазақстанның алдында экономиканың тұрақты өсуін қамтамасыз ету бойынша күрделі міндеттер тұратындығымен, оларды шешу көп жағдайда инвестициялық саясатқа байланысты болумен айқындалады. Ел экономикасының басты ерекшелігі технологиялық біркелкіліктің жоғары деңгейі болғандықтан, елімізде 2010 жылдан бастап жүзеге асырылып жатқан жаңа индустриялық саясат салалардың технологиялық артта қалуын жоюға, капиталдың жаңаруын қамтамасыз етуге, жаңа инновация нүктелерін құруға бағытталған. және инвестицияның өсуі. Мақаланың мақсаты - оның жалпыланған көрсеткіштерін талдау негізінде Қазақстанның инвестициялық саясатының негізгі мәселелерін анықтау және оны орта мерзімді перспективада жетілдірудің бағыттарын тұжырымдау. Жаһандық трендтерден кейін Қазақстан жаңартылатын энергия көздерін пайдалануға төртінші энергетикалық көшу кезеңіне өтуде. Дегенмен, ел экономикасының энергияға тәуелділігінің жалғасуы әлемдік нарықта шикізат бағасының төмендеуі тау-кен өндіруші кәсіпорындардың әлемдік нарықтағы бәсекелестік жағдайын төмендететініне әкеледі. Жоғарыда айтылғандарды ескере отырып және жаңартылатын энергия көздері саласы жақын болашақта ең тартымды инвестициялық салаға айналатынын ескере отырып, авторлар баламалы энергетиканы дамыту саласына шетелдік капитал мен озық технологияларды тарту, ортаны жақсарту бойынша кұрылымдық шаралардың маңыздылығын атап көрсетеді. Қазақстан үшін, сондай-ақ өтпелі экономикасы бар басқа елдер үшін инвестициялық саясатты жетілдірудің жаңа бағыттарын іздеуді. Қазақстанның инвестициялық тартымдылығының өсуіне кедергі келтіретін ең маңызды факторлар мемлекеттің рөлін күшейтумен, мемлекеттік-жекеменшік әріптестікті жандандырумен жүйелі көзқарасты талап ететіні дәлелденді. Ұлттық салалардың күрделене түсуі жағдайында Қазақстанның инвестициялық саясатты жетілдірудегі қарастырылған тәжірибесі өтпелі экономикасы бар елдердегі трансформациялық қайта құруларды терең зерттеу үшін пайдалы болуы мүмкін.

Түйін сөздер: транзиттік экономика, Қазақстан, әртараптандыру, мемлекеттік реттеу, тікелей шетел инвестициялары, экономиканы декарбонизациялау.

Дәйексөз алу үшін: Аубакирова Г.М., Мажитова С.К., Исатаева Ф.М., Томашинова А.Е. (2021). Транзиттік экономикасы бар елдердің инвестициялық саясатын жетілдіру: Қазақстан тәжірибесі. Экономика: стратегия және практика, 16(4), 46-61, https://doi.org/10.51176/1997-9967-2021-4 -46-61

* Хат-хабаршы авторы: Исатаева Ф.М. - PhD докторы, Қарағанды техникалық университеті, 34 Нұржанова, Геология және пайдалы қазбаларды барлау кафедрасының меңгерушісі, 100000, Қарағанды, Қазақстан, 87016064653, e-mail: adambekova_farid@mail.ru

Мүдделер қақтығысы: авторлар мүдделер қақтығысының жоқтығын мәлімдейді..

Қаржыландыру. Зерттеу демеушілік қолдау көрсеткен жоқ (меншікті ресурстар)

Мақала редакцияға түсті: 09.12.2021

Жариялау туралы шешім қабылданды: 29.12.2021

Жарияланды: 30.12 .2021 


\title{
Совершенствование инвестиционной политики стран с транзитной экономикой: опыт Казахстана
}

\author{
Аубакирова Г.М. ${ }^{1}$, Мажитова С.К. ${ }^{2}$, Исатаева Ф.М. ${ }^{*}$, Томашинова А.Е. ${ }^{2}$ \\ ${ }^{1}$ Карагандинский технический университет, пр. Н. Назарбаева, 56, 100027, Караганда, \\ Казахстан \\ ${ }^{2}$ Карагандинский университет Казпотребсоюза, ул. Академическая, 9, 100009, Караганда, \\ Казахстан
}

\begin{abstract}
Аннотация
Актуальность исследования определяется тем, что перед Казахстаном стоят сложнейшие задачи по обеспечению устойчивого роста экономики, решение которых в немалой степени зависит от инвестиционной политики. Поскольку ключевой особенностью экономики страны является высокий уровень технологической неоднородности, то новая индустриальная политика, реализуемая в стране с 2010 года, призвана устранить технологическое отставание отраслей, обеспечить обновление капитала, создать новые точки инновационноинвестиционного роста. Целью статьи является выявление основных проблем инвестиционной политики Казахстана, основываясь на анализе ее обобщающих показателях, и формулирование направлений ее совершенствования в среднесрочном периоде. Следуя мировым трендам, Казахстан вступает в этап четвертого энергетического перехода к использованию возобновляемых источников энергии. Однако сохраняющаяся зависимость экономики страны от энергетики приводит к тому, что снижение цен на сырьевые товары на мировых рынках снижает конкурентные позиции горнодобывающих предприятий на мировом рынке. В свете сказанного и учитывая, что сфера возобновляемых источников энергии в обозримом будущем станет наиболее привлекательным участкам инвестирования, авторы подчеркивают значимость структурных мер по улучшению инвестиционной среды для привлечения иностранного капитала и прогрессивных технологий в отрасль развития альтернативной энергетики. Обосновано, что важнейшие факторы, препятствующие наращиванию инвестиционной привлекательности Казахстана, требуют системного подхода с усилением роли государства, активизации государственно-частного партнерства. В условиях усложнения национальных производств рассмотренный опыт Казахстана по совершенствованию инвестиционной политики может быть полезен для углубленного изучения трансформационных преобразований в странах с транзитной экономикой.
\end{abstract}

Ключевые слова: транзитная экономика, Казахстан, диверсификация, государственное регулирование, прямые иностранные инвестиции, декарбонизация экономики.

Для цитирования: Аубакирова Г.М., Мажитова С.К., Исатаева Ф.М., Томашинова А.Е. (2021). Совершенствование инвестиционной политики стран с транзитной экономикой: опыт Казахстана. Экономика: стратегия и практика, 16(4), 46-61, https://doi.org/10.51176/1997-9967-2021-4 -46-61

* Корреспондирующий автор: Исатаева Ф.М. - доктор $\mathrm{PhD}$, Карагандинский технический университет, Нуржанова 34, заведующий кафедрой «Геология и разведка месторождений полезных ископаемых», 100000, Караганда, Казахстан, 87016064653, e-mail: adambekova_farid@mail.ru

Конфликт интересов: авторы заявляют об отсутствии конфликта интересов.

Финансирование. Исследование не имело спонсорской поддержки (собственные ресурсы).

Статья поступила в редакцию: 09.12.2021

Принято решение о публикации: 29.12.2021

Опубликовано: 30.12.2021 


\section{Введение}

В контексте продвижения к национальным идеям и перехода на инклюзивную, «человекоцентричную» экономическую модель Казахстан укрепляет геостратегические позиции на международных рынках, проводит глубокую структурную трансформацию, активизирует инвестиционную политику.

Актуализация для Казахстана, как и других стран с транзитной экономикой поиска новых направлений улучшения инвестиционной политики во многом продиктовано обострившейся борьбой за инвестиции на мировом рынке и курсом некоторых развитых стран на политику их репатриации.

Государственное регулирование достижения целей по мобилизации иностранного капитала в экономику Казахстана затрагивает самые различные аспекты участия зарубежных инвесторов в конкретных отраслях, создания новых условий для усиления конкуренции среди иностранных инвесторов за казахстанский рынок, гармонизацию отечественных стандартов с международными и национальными стандартами стран-партнеров [1-3].

Поскольку до сих пор в глобальных цепочках добавленной стоимости страна представлена главным образом как поставщик сырья и изделий низких переделов, то прямые иностранные инвестиции (ПИИ) для Казахстана это не только драйвер диверсификации экспортоориентированной экономики и источник капитализации. Это шанс подключиться к сбытовым рынкам, интегрируясь в международные цепочки поставок.

В средне и долгосрочном периоде изменение структурной политики, разработка новых механизмов государственного регулирования промышленной политики [4, 5], приведут к усложнению структуры национальной экономики и соответствующему росту конкурентных позиций на мировых рынках. Политика государства будет нацелена на то, чтобы иностранные инвестиции привели к ускоренному обновлению отраслей обрабатывающей промышленности, а не были сосредоточены лишь на получение ренты в сырьевых секторах.

В рамках настоящей статьи ставилась цель проанализировать обобщающие показатели инвестиционной политики Казахстана, выявив ключевые проблемы и обозначить основные направления ее совершенствования.

\section{Литературный обзор}

Ситуация с притоком ПИИ во всем мире была напряженной еще за несколько лет до пандемии из-за неопределенности в торговой политике развитых стран, набирающего мощь протекционизма и перестройки в сфере производства [6]. Пандемия COVID-19, ухудшив перспективы мировой торговли и инвестиций, усилив влияние на глобальное падение спроса и продаж, стала новым инвестиционный риском особенно для стран с переходной экономикой, прежде всего, из-за уязвимости сырьевого сектора.

По прогнозным оценкам, если в 2019 году государства с переходной экономикой получили извне 55 млрд. долл., то в 2020-2021 годах сумма чистых ПИИ, исключающих затраты по амортизации и показывающих реальное увеличение производственных активов, сократится до 30-40 млрд. долл. Восстановление потоков ПИИ в эти страны ожидается только в 2022 году [7].

Среди стран с высокой зависимостью от минеральных ресурсов, Казахстан находится на переходной стадии от эффективного развития к инновационному, и на текущий момент относится к странам, где промышленный рост еще не сопровождается ростом производительности [8]. Встроиться в глобальные цепочки производства страна пытается путем институциональных преобразований, производства высокотехнологичной продукции с высокой степенью переработки [9], адаптации положительного опыта стран с транзитной экономикой, предполагающего использование в экономике иностранного капитала, что подробно раскрывается в работе Хануш Х. и др. [10].

Отечественным предприятиям следует обратить внимание на возрастающую значимость услуг в глобальных цепочках со-здания стоимости и мировом экспорте, чему посвящена работа ученых ИМЭМО им. E.M. Примакова Кондратьева В., Кедровой Г. и Попова В. [11]. По мнению Сако М. и Зильберберга Е. [12] это позволит разрабатывать собственные наиболее приемлемые в сложившихся ситуациях компетенции, минимизирующие риски и повышающие устойчивость обозначенных цепочек Тем более, что в посткризисный период предприятия должны наряду с восстановлением позиций в функционирующей рыночной среде, активизировать поиск альтернативных вариантов реализации товаров.

Для развивающихся стран, в частности, азиатских, как это показано в работе Ли К. и др. [13], активная инвестиционная политика 
неразрывно связана с цифровой трансформацией и внедрением высокотехнологичных проектов по перспективным направлениям становления нового технологического уклада ускорением перехода к низкоуглеродной экономике и взаимовыгодному сотрудничеству с партнерами [14-16].

Как показывают исследования развивающихся экономик, налоговые льготы и стимулируют инвестиционные процессы, на что указывают Клемм А. и Парис С. [17], и препятствуют реализации инвестиционной политики, достижению компромисса государства и инвестора, что подтверждают результаты исследований Золт Э. [18].

В многочисленных научных работах подтверждается возрастающая значимость инвестиционной политики для горнодобывающей и металлургической отраслей развивающихся стран [19-22]. В своих исследованиях Вивода В. [23] обосновывает необходимость объективной оценки воздействия различных факторов, определяющих вклад прямых иностранных вложений в достижение промышленного роста.

Ученые Макки П. и др. [24] заостряют внимание на роли иностранных инвестиций для развития инфраструктуры, что для Казахстана представляет несомненный интеpec, поскольку, например, проблемы освоения месторождений и строящейся инфраструктуры в несырьевом секторе экономики в разрезе разных регионов (особенно депрессивных), по мнению профессора Нурлановой Н.К. как никогда требуют безотлагательного решения [25].

\section{Методология}

При написании статьи была использована классическая методология оценки и тенденций изменения иностранных инвестиций в рамках долгосрочной стратегии развития государства, базирующаяся на исследованиях Конференции ООН по торговле и развитию (ЮНКТАД) и ОЭСР. В частности, по мнению авторов на методики, учитывающие специфику трансформации инвестиционной политики в странах с транзитной экономикой, демонстрирующие роль государства в обосновании инвестиционный решений, а также предпринимаемые государством шаги для стимулирования инвестиционной активности бизнеса.

Методология аналитического исследования базируется на системном подходе, предполагающем оценку инвестиционных процессов Казахстана. Использованы общеизвестные концепции и понятия, ретро- спективная и сравнительная оценка инвестиционной политики Казахстана. Научнометодический аппарат включает причинноследственный, текущий и перспективный анализ трансформационных процессов в экономике страны.

Эмпирическая база исследования представлена статистическими данными Бюро национальной статистики Агентства по стратегическому планированию и реформам Республики Казахстан и проекта по мониторингу экономики Казахстана в формате рэнкингов. В работе проанализирована информация авторитетных международных организаций и публикаций по обозначенной тематике в научных журналах, профессиональных и отраслевых изданиях.

Ограничивающим фактором проведенного исследования стал недостаток корректных статистических данных по рассматриваемым вопросам. Однако, благодаря прозрачности отдельных показателей открытого доступа, получены результаты, которые, по мнению авторов, углубят представление о значимости ПИИ в построении Казахстаном новой модели экономического прогресса.

\section{Результаты и обсуждение}

За годы независимости совокупный объем валового притока ПИИ в экономику Казахстана составил около 350 млрд. долл., самый существенный рост наблюдался в 20002010 годах, за второй этап индустриальноинновационной политики (2015-2019 годы) ежегодно в страну были привлечены в среднем около 21,3 млрд. долл. ПИИ [26].

Среди стран СНГ Казахстан один из первых получил инвестиционный страновой рейтинг и был включен Всемирным Банком в двадцать наиболее привлекательных стран для инвестиций. Благодаря внедрению новых подходов по привлечению инвестиций и налаживанию сотрудничества с инвесторами, в 2017 году. Казахстан присоединился к Декларации ОЭСР по международным инвестициям и многонациональным предприятиям. FDi Intelligence (дочерняя организация Financial Times) присвоила Казахстану первое место по показателю «Эффективность затрат на будущее расположение производственных мощностей 2018/2019 годов» [27].

Казахстан усилил позиции в международных рейтингах, отражающих состояние бизнес-климата и регуляторной среды. Так, в рейтинге Всемирного банка «Doing Business 2020» стране отведено общее 25-е место из 190 стран, причем по таким показателям как «Защита прав миноритарных инвесторов» 
и «Обеспечение исполнения контрактов» страна вошла в первую десятку [27]. Улучшив бизнес-климат и качество институтов, Казахстан превзошел страны Центральной Азии, испытывающих такую же потребность в привлечении внешних источников для усиления инвестиционного потенциала, уступив лишь Узбекистану по скорости развития и привлечения инвестиций.

На сегодняшний день, Казахстан, не имея прямого выхода к морю, но занимая выгодное географическое положение благодаря нахождению между Европой и Азией, из-за совместных сухопутных границ с Китаем и Россией, ограничен в выборе приоритетного направления по привлечению иностранных инвестиций. Стратегическое положение страны как основного коридора, связываю- щего Китай с Россией и Европой посредством новых железнодорожных и автодорожных сетей, дает возможность быть основным «звеном» в китайской инициативе «Один пояс - один путь» [28].

В 2019 году среди стран с переходной экономикой, Казахстан занимал третье место по объему привлеченных чистых прямых инвестиций. В 2020 году, на фоне уменьшения на 35\% объема чистых ПИИ в Центральную Азию, Казахстан продемонстрировал наибольший их прирост среди стран с переходной экономикой и стран, не имеющих выхода к морю. При этом ключевую роль сыграли инвестиции в горнодобывающую отрасль, обрабатывающую промышленность, транспорт, финансовую сферу, энергетику [7] (таблицы 1 и 2).

Таблица 1 - Позиции Казахстана по притоку чистых ПИИ среди стран без выхода к морю Table 1 - Positions of Kazakhstan in terms of net FDI inflows among landlocked countries

\begin{tabular}{|c|l|c|c|}
\hline № п/п & Страны без выхода к морю & $\begin{array}{c}\text { Изменение в 2020 г. } \\
\text { в сравнении с 2019 г., } \%\end{array}$ & $\begin{array}{c}\text { Приток чистых ПИИ } \\
\text { за 2020 г., млрд. долл. }\end{array}$ \\
\hline 1 & Казахстан & $+34,9$ & 3,9 \\
\hline 2 & Парагвай & $+9,0$ & 0,5 \\
\hline 3 & Лаос & $+7,0$ & 0,9 \\
\hline 4 & Эфиопия & $-6,0$ & 2,4 \\
\hline 5 & Узбекистан & $-25,5$ & 1,7 \\
\hline 6 & Монголия & $-29,6$ & 1,7 \\
\hline 7 & Туркменистан & $-45,1$ & 0,507 \\
\hline 8 & Азербайджан & $-66,0$ & 0,117 \\
\hline 9 & Армения & $-53,9$ & 0,055 \\
\hline 10 & Молдова & $-89,0$ & \\
\hline \hline
\end{tabular}

Примечание - Источник: [7]

Таблица 2 - Позиции Казахстана по притоку чистых ПИИ среди стран с переходной экономикой

Table 2 - Positions of Kazakhstan in terms of net FDI inflows among countries with economies in transition

\begin{tabular}{|c|l|c|c|}
\hline \multirow{2}{N}{ N п/п } & \multicolumn{1}{|l}{ Переходные экономики } & $\begin{array}{c}\text { Изменение в 2020 г. } \\
\text { в сравнении с 2019 г., } \%\end{array}$ & $\begin{array}{c}\text { Приток чистых ПИИ } \\
\text { за 2020г., млрд. долл. }\end{array}$ \\
\hline 1 & Казахстан & $+34,9$ & 3,9 \\
\hline 2 & Черногория & $+21,0$ & 0,5 \\
\hline 3 & Беларусь & $+8,0$ & 1,4 \\
\hline 4 & РФ & $-69,8$ & 9,6 \\
\hline 5 & Сербия & $-19,4$ & 3,4 \\
\hline 6 & Узбекистан & $-25,5$ & 1,7 \\
\hline 7 & Албания & $-14,1$ & 1,1 \\
\hline 8 & Грузия & $-52,9$ & 0,6 \\
\hline 9 & Азербайджан & $-66,0$ & 0,1 \\
\hline 10 & Украина & $-114,6$ & $-0,8$ \\
\hline
\end{tabular}

Примечание - Источник: [7] 
Казахстан стремится удержать лидерство по объёму привлечённых инвестиций в центрально азиатском регионе, обеспечивая реализацию заключенных договоров, активизируя диалог с действующими инвесторами, наращивая прозрачность, которую иностранные инвесторы ценят на всех уровнях, в том числе в нормотворчестве, правоприменении, закупках со стороны государства и государственных предприятий $[7,8,29]$ (таблица 3).

Таблица 3 - Показатели инвестиционной политики стран Центральной Азии Table 3 - Indicators of investment policy in Central Asian countries

\begin{tabular}{|c|c|c|c|c|c|}
\hline \multirow{2}{*}{ Страны } & \multicolumn{7}{c|}{ Год } \\
\cline { 2 - 6 } & 2016 & 2017 & 2018 & 2019 & 2020 \\
\hline \multicolumn{7}{|c|}{ Валовой приток ПИИ в страны Центральной Азии, млрд. долл. } \\
\hline РК & 21,4 & 21,0 & 24,3 & 24,3 & 2,9 \\
\hline Узбекистан & 3,7 & 2,4 & 1,8 & 4,2 & 0,5 \\
\hline Кыргызстан & 0,8 & 0,6 & 0,9 & 1,1 & 0,2 \\
\hline Таджикистан & 0,3 & 0,3 & 0,4 & 0,4 & 232,6 \\
\hline \multicolumn{7}{|c|}{ Обязательства резидентов стран Центральной Азии перед иностранными инвесторами } \\
\hline \multicolumn{7}{|c|}{ РКо состоянию на 01.01 соотетствующего года), млрд. долл. } \\
\hline Узбекистан & 218,3 & 227,1 & 220,0 & 224,5 & 45,6 \\
\hline Кыргызстан & 11,4 & 26,0 & 27,1 & 35,1 & 12,3 \\
\hline Таджикистан & 6,1 & 7,0 & 7,4 & 12,3 & 8,0 \\
\hline
\end{tabular}

Примечание - Источник: [7, 8, 29]

Для Казахстана решающую роль в наращивании инвестиционной привлекательности играют макроэкономическая стабильность, улучшение государственных институтов, интерес инвесторов к полезным ископаемым, нефтепереработке, нефтедобыче и химической промышленности, возможностям новых рынков для неторговых секторов. При разработке инвестиционной политики, упор делается на обеспечение национальной безопасности и конкурентоспособности местных производителей, защиту стратегических отраслей от возможного контроля иностранными инвесторами.

Основной объем привлеченных ПИИ приходится на горнодобывающую промышленность (основная отрасль-бенефициар ПИИ) и разработку карьеров (например, в 2019 году горнодобывающая промышленность составила $56,3 \%$ всего валового притока ПИИ) и смежные отрасли (в частности, геологоразведку). В 2020 году, несмотря на общий экономический спад на 2,6\%, горнометаллургический комплекс смог показать рост производства на 14,4\%. Впервые с 2010 года вклад обрабатывающей промышленности в экономическое развитие превысил долю горнодобывающей отрасли, составив $13 \%$. Рост показателей экспорта переработанной продукции был получен за счет инвестиционных проектов в горно-металлургический комплекс, вводом в эксплуа- тацию новой обогатительной фабрики экспортоориентированного предприятия с элементами «Индустрии 4.0», входящей в Актогайский горно-обогатительный комплекс группы KAZ Minerals.

Устойчивый интерес к горно-металлургическому комплексу, переработке и экспорте готовых продуктов, твердым полезным ископаемым наблюдается у крупных инвесторов, для которых характерна высокая социальная ответственность, готовность платить налоги, покрывать операционные расходы, внося свой вклад в развитие места дислокации производства.

В 2020 году приток ПИИ в Казахстан уменьшился на 42,1\% из - за сокращения глобальных потоков ПИИ и пересмотра крупнейшими транснациональными корпорациями своих проектов в развивающихся странах (таблицы 3 и 4) [30].

Валовый объем накопленных ПИИ в Казахстане, несмотря на то, что 2017-2019 годы характеризовались высокой волатильностью, оказался значителен. Увеличение накопленных иностранных инвестиций объясняется во многом наличием инфраструктуры для привлечения внешних инвесторов и развитием казахстанского рынка капитала, открывающего перед инвесторами новые возможности на развивающихся рынках. 
Таблица 4 - Показатели инвестиционной политики Казахстана

Table 4 - Indicators of investment policy in Kazakhstan

\begin{tabular}{|c|c|c|c|c|c|c|}
\hline \multirow[t]{2}{*}{ Показатель } & \multicolumn{6}{|c|}{ Год } \\
\hline & 2014 & 2015 & 2016 & 2017 & 2018 & 2019 \\
\hline \multicolumn{7}{|c|}{ Чистый приток ПИИ в РК, млн. долл.: } \\
\hline -добыча нефти и газа & 3,393 & 852 & 2,098 & 4,115 & 4,088 & 4,813 \\
\hline \multicolumn{7}{|c|}{ Валовой приток ПИИ в РК } \\
\hline -млрд. долл. & 23,8 & 15,4 & 21,4 & 21,0 & 24,3 & 24,1 \\
\hline -прирост, \% & $-1,2$ & $-35,3$ & 38,9 & $-1,9$ & 15,7 & $-0,8$ \\
\hline \multicolumn{7}{|c|}{ Валовый отток ПИИ из РК } \\
\hline млрд. долл. & 3,3 & 6,9 & 4,2 & 1,9 & 1,3 & 2,6 \\
\hline -прирост, \% & $-61,4$ & 109,1 & $-39,1$ & $-54,8$ & $-31,6$ & 100,0 \\
\hline \multicolumn{7}{|c|}{ Действующие предприятия Казахстана с иностранным участием: } \\
\hline -тыс. ед. & 15,3 & 16,9 & 20,7 & 23,9 & 17,7 & 20,5 \\
\hline -прирост, \% & 8,1 & 10,4 & 22,4 & 15,6 & $-25,9$ & 15,8 \\
\hline $\begin{array}{l}\text { Накопленные иностранные } \\
\text { инвестиции, млрд. долл. }\end{array}$ & 189,3 & 197,7 & 218,3 & 227,1 & 220,0 & 224,5 \\
\hline
\end{tabular}

Примечание - Источник: данные Бюро национальной статистики АСПиР РК https://stat.gov.kz и Ranking.kz проекта по мониторингу экономики Казахстана в формате рэнкингов http://ranking.kz/page/o_proekte

За 2015 - 2019 гг. из 106,1 млрд. долл. валового притока ПИИ, наибольший объем в разрезе стран приходился на Нидерланды - 34,3 млрд. долл. $(32,3 \%$ в основном нефтедобывающую отрасль), США - 20,8 млрд. долл. (19,6\%) и Швейцарию - 12,4 млрд. долл. $(11,7 \%)$. Совокупная доля этих стран превышает $60 \%$ от общего объема валового притока ПИИ.

При фокусировании деятельности по привлечению инвестиций на диверсификации экономики Казахстана в приоритетных секторах, внимание должно быть сосредоточено на конкретных отраслевых потребностях. Это отрасли с действующим потенциалом, так называемые источники сравнительных конкурентных преимуществ Казахстана, имеющие мультипликативный эффект и выступающие основой для формирования кластера, уже готовые для привлечения инвестиций и развития экспортного производства, (пищевая промышленность, глубокая переработка полезных ископаемых, металлургия, химия и нефтехимия, отдельные машиностроительные сектора, информационные технологии, транспорт и логистика). И перспективные отрасли с более продолжительным инвестиционным горизонтом (информационно-коммуникационные технологии, туризм и финансы). Отраслям, накопившим сравнительное преимущество за счет технологического обновления, должно быть оказано государственное содействие для встраивания в глобальные цепочки добавленной стоимости.
Присоединившись к Глобальному договору ООН и поддержав его ключевые инициативы, Казахстан реализует Цели устойчивого развития, ускоряет переход к зеленой экономике, обеспечивает условия для развития человеческого капитала, стремится к внедрению оценки ESG-факторов на всех этапах инвестиционного процесса - от поиска проектных предложений до мониторинга экологического и социального воздействия проектов на экономику.

Сфера возобновляемых источников энергии, является одним из наиболее привлекательных участков инвестирования. Поскольку правительство предлагает привлекательные инвестиционные условия для частных инвесторов, устойчивая энергетика остается ключевым долгосрочным приоритетом для государства. Реализация структурных мер по улучшению инвестиционной среды для привлечения иностранного капитала и передовых технологий в отрасль развития альтернативной энергетики позволила только в 2020 году ввести в эксплуатацию 25 проектов в сфере возобновляемой энергетики с объемом инвестиций 510 млн. долл.

Наращивание притока ПИИ предполагает как привлечение новых инвесторов, так и поддержание сотрудничества с инвесторами, реализующими относительно недорогие и быстроокупаемые проекты, ориентированные на изготовление изделий с невысокой степенью переработки в Казахстане. Основной приоритет в привлечении инвестиций ввод в эксплуатацию проектов в перерабатывающей промышленности. По сравнению 
с 2010 годом, когда доля инвестиций в обрабатывающую промышленность составляла $10 \%$, в 2020 году ее значение возросло до 19\%. До конца 2021 года запланирован ввод 36 проектов на 4,4 млрд. долл.

Несмотря на спад в привлечении ПИИ в 2020 году, благодаря принятым Правительством своевременным мерам по предотвращению срыва сроков сдачи проектов и привлечению новых инвесторов, запланированный 41 проект на 1,6 млрд. долл. с созданием 7 тыс. рабочих мест, был выведен на проектную мощность. Благодаря переводу на онлайн-платформу процесса заключения инвестиционных контрактов, Казахстан подтвердил свыше 20 контрактов на 300 млрд. тенге.

C целью налаживания местного производства впервые в 2020 году были выявлены наиболее перспективные товарные группы и нишевые проекты. Для иностранных инвесторов подготовлены 70 предложений, в том числе у 63 проектов есть местные партнеры и 7 - это отраслевые тизеры [31].

Благодаря транзитному потенциалу Казахстана, в частности запуску мульдимодального Евразийского транспортного коридора, транзит интернет-графика между Европой и Азией, востребованы логистические проекты. Инвесторов могут заинтересовать инфраструктурные проекты, в том числе инфокоммуникации, транзит грузов и цифровых данных. Казахстану предстоит развивать волоконно - оптические линии связи, международные маршрутные коридоры, обсуживающие цифровой транзит. В частности, вычислительные мощности четырех строящихся мегацентров обработки данных в гг. Нур-Султане, Алматы, Шымкенте и Атырау, будут расположены на крупной международной информационной магистрали.

Для выработки целенаправленных действий по улучшению инвестиционного климата конкретизированы подходы к привлечению инвестиций, разработаны меры системного и оперативного характера.

Системные меры активизируют глобальных инвесторов и международные финансовые институты развития.

Преобразования и реформы, нацеленные на повышение инвестиционной привлекательности Казахстана, предполагают реализацию конкретных механизмов, включая создание новых гибких инвестиционных инструментов. Так, с 2021 г. введено Стратегическое инвестиционное соглашение для стратегических инвесторов - новый инвестиционный инструмент, обеспечиваю- щий гарантированную стабильность законодательных условий со стороны государства, предоставляющий особые условия именно для инвесторов, ориентированных на долговременное пребывание в Казахстане.

Способствуют росту инвестиционной привлекательности страны финансовые институты, предлагающие доступ к финансированию в различных форматах. Из разных категорий инвестиций (фондовый рынок, фонды прямых инвестиций и непосредственно финансы иностранных компаний) в Казахстане фондовый рынок и фонды прямых инвестиций, позволяющие реализовать крупные инвестиционные проекты на принципе соинвестирования, еще находятся в стадии становления. Корпоративным венчурным фондам отведена ведущая роль в освоении нововведений, в рамках сотрудничества с национальными компаниями, недропользователями и зарубежными компаниями, задействованными в инвестиционной сфере.

В увеличении притока инвестиций надежды возлагаются на развитие таких институтов, как МФЦА и KASE. Через МФЦА в экономику страны поступило более 180 млн. долл. инвестиционных средств. Участникам МФЦА предоставляются налоговые льготы до 50 лет и льготы на операционную деятельность, помогающие снизить издержки, действует упрощенный валютный, визовый и трудовой режим. Для эффективной реализации проектов осуществляется индивидуальный подход к каждому крупному инвестору, достигается максимальная открытость и прозрачность на всех уровнях. Отдельная юрисдикция, правовая база, суд с привлечением профессиональных зарубежных специалистов, должны стать новым импульсом для прихода инвесторов.

Фондовая биржа МФЦА (AIX), предоставляющая полный бизнес-цикл, обеспечивающий торги, расчётно-клиринговые операции, регистрацию передачи данных и IT-услуги, открывает выход на евразийский рынок для мирового инвестиционного сообщества и стран континента с доступом к глобальным рынкам капитала и возможностью привлечения новых инвестиций. Через биржу компании привлекли 290 млн. долл. в виде акционерного капитала, в ее Центральном депозитарии открыто более 63 тыс. счетов инвесторов.

Несмотря на положительные результаты, отметим, что низкий уровень развития финансовых рынков в Казахстане остается серьезным препятствием для привлечения 
международных частных и институциональных инвесторов.

В рамках операционного подхода, включающего реализационные и сопроводительные процедуры кратковременных инвестиционных сделок, впервые введен алгоритм управления инвестициями в сочетании с адресной работой по инвесторам. Вопросы практического характера, затрагивающие инвестиционные проекты, решаются специально созданным Инвестиционным штабом. Помимо этого, исключительно для продвижения проектов стратегического характера, реализуемых главным образом в обрабатывающей промышленности, сформирована переговорная команда Task Force, которой доверено право вести переговоры от лица Правительства Казахстана. Для центральных и местных государственных органов установлены пятилетние показатели, позволяющие оценить инвестиционные вложения в основной капитал, эффективность ПИИ в масштабе конкретного региона.

Для стимулирования инвестиционной деятельности расширен спектр инвестиционных преференций (льготы (освобождение от обложения таможенными пошлинами и налогом на добавленную стоимость на импорт); государственные натурные гранты в размере до $30 \%$ от объема инвестиций; инвестиционные субсидии; освобождение от обложения таможенными пошлинами), ориентированных на проекты, как приоритетные, так и специальные. В частности, преференции распространяются на предприятия, реализующие инвестиционные проекты и лизинговые предприятия, импортирующие в рамках инвестиционного проекта технологическое оборудование. Обозначенные преференции применимы к действующим в Казахстане 13 специальным экономическим зонам, период функционирования которых возрос с 25 до 49 лет, и 24 индустриальным зонам, где в рамках индивидуального подхода к каждому инвестору государством предоставляется продолжительность действия льготного пакета, определяемого масштабом инвестиций и сроком окупаемости реализуемого проекта.

В рамках созданной трехуровневой системы привлечения инвестиций разработаны пятилетние инвестиционные программы для разных стран с указанием отраслей и предприятий, подлежащих таргетированию. Это позволит посольству Казахстана в течение месяца проводить одновременно индивидуальную работу с инвесторами, формируя для отраслевых и региональных органов «short list».
Для улучшения бизнес-климата и совершенствования управления процессом по привлечению инвестиций в 2017 г. введена единая информационная система мониторинга Customer Relationship Management (CRM), содержащая полную, достоверную и актуальную информацию об инвесторах, инвестиционных проектах, производственных площадках и информационных запросах потенциальных инвесторов.

Для повышения комфортности условий работы в Казахстане иностранных инвесторов внедрена система раннего реагирования на проблемные вопросы инвесторов; разработаны новые механизмы борьбы с коррупцией; совершенствуется правоприменительная практика, введен мониторинг соблюдения законодательства при проведении проверок субъектов инвестиционной деятельности и недопущения нарушения норм законодательства со стороны государственных органов.
Благодаря
созданию
института

Инвестиционного омбудсмена - инструмента досудебного и внесудебного урегулирования споров, способствующего активизации сотрудничества с инвесторами, работающими в стране, в 2019 году инвесторы получили содействие при рассмотрении 70 вопросов, в 2020 году обсуждались 69 обращений.

В рамках формирования новой регуляторной системы, все контрольно-надзорные, разрешительные, регуляторные инструменты подверглись тщательной ревизии. В 2021 году усилена защита инвесторов от коррупционного давления. Более 500 бизнес-проектов с объемом финансирования свыше 12 трлн. тенге охвачены антикоррупционным сопровождением Агентства по противодействию коррупции [32].

В целом, проведенный анализ позволяет заключить следующее:

- для роста инвестиционной привлекательности, Казахстан стремится к эффективному управлению и устойчивому законодательному регулированию всех сторон инвестиционной деятельности; доминирующими элементами системы государственного регулирования остаются либерализация политики и поощрение инвестиционной активности;

- невзирая на глобальный кризис, благодаря предпринимаемым действенным шагам по улучшению инвестиционного климата, созданию дополнительных стимулов для инвесторов и защите их интересов (упрощённый налоговый режим, национальное законодательство, инвестиционные преференции, совершенствование регуля- 
торной системы, повышение защиты инвесторов от коррупции), активизируется процесс привлечения инвестиций в Казахстан. Страна остаётся привлекательной для внешних инвестиций, лидирует по показателю притока иностранных инвестиций в центрально азиатском регионе;

- благодаря системной работе по разъяснению специфики законодательства Казахстана, росту прозрачности принимаемых решений, уменьшению административной нагрузки, в стране выстроена «мягкая инфраструктура» для инвесторов (в частности использование потенциала МФЦА для привлечения прямых инвестиций и развития фондового рынка (обеспечение доступа казахстанских предпринимателей к использованию английского права и арбитража; поэтапный перевод отдельных структур, принадлежащих национальным компаниям из иностранных юрисдикций в МФЦА; усиление продвижения программы инвестиционного налогового резидентства); разработаны предложения по обеспечению стабильности инвестиционного законодательства для стратегических проектов (формирование страновых инвестиционных программ и индивидуальных планов реализации для крупных инвестиционных проектов с разработкой точечных мер поддержки к каждому инвестору на основе приоритетности и потенциального эффекта на экономику в целом).

Проведенное исследование показывает, что, основными проблемами для достижения прибыльности инвесторами остаются колебания курса иностранной валюты, девальвация, коррупция, относительно низкое качество финансовой и управленческой отчетностей, местное банковское финансирование и инфраструктура.

Тем не менее, есть все основания полагать, что при соответствующей государственной политике иностранные инвестиции могут способствовать наращиванию инвестиционного потенциала Казахстана. Страна может привлекать иностранных инвесторов не только своим стратегически выгодным местоположением, доступностью ресурсов и относительно недорогой рабочей силой, но главным образом, государственным регулированием инвестиционной политики, реализацией конкретных шагов для построения новой модели глобализации в контексте достижения устойчивого развития и декарбонизации национальной экономики.

\section{Заключение}

На фоне усиления международного торгового протекционизма, обострения конкуренции между странами с транзитной экономикой за привлечение инвестиций в обрабатывающую промышленность из промышленно развитых стран, в среднесрочном периоде инвестиционная активность Казахстана будет во многом определяться воздействием ряда факторов. В частности, денежно-кредитная политика промышленно развитых стран, зависимость от экономической ситуации в странах - ключевых торговых партнеров, рыночная конъюнктура на международном и локальном рынках, выраженная в снижении мировых цен на нефть и волатильности национальной валюты, эпидемиологическая ситуация и непредсказуемость рыночного поведения транснациональных корпораций.

В сложившихся условиях наращивание притока иностранных инвестиций в Казахстан предполагается за счет улучшения эпидемиологической ситуации, восстановительного роста экономики стран - партнеров и в целом мировой экономики. Новые возможности укрепления позиций страны в международных производственно - сбытовых цепочках откроет реализация проактивной стратегии по декарбонизации ключевых промышленных секторов и энергетической отрасли.

Для достижения ежегодного роста инвестиций в основной капитал обрабатывающей промышленности за 2020-2027 годы в размере $109,8 \%$, выхода на планируемый в 2025 г. объем валового притока ПИИ в 30 млрд. долл. акцент должен быть сделан на трансформационное преобразование реального сектора [27].

С целью укрепления устойчивости слабо диверсифицированной экономики Казахстана и адекватной реакции на системные вызовы необходимы структурно-функциональное обновление, технологическая трансформация и освоение промышленного производства изделий с высокой добавленной стоимостью:

- с учетом отраслевых приоритетов привлечения иностранных инвестиций и специфических конкурентных преимуществ Казахстана в ряде отраслей, крайне необходимо как улучшение инвестиционного климата в целях активизации привлечения иностранных инвестиций, так и активное расширение их сфер приложения в несырьевых отраслях (ITотрасль, геологоразведка; нефтехимическая отрасль); 
- для предотвращения возникновения рисков волатильности бизнес-модели, упор должен быть сделан на разработку институциональных мер для стимулирования инвесторов с акцентом на стабильность законодательства, степень защищенности вложений, прозрачность бизнес-среды. Для защиты инвесторов от валютных рисков и роста инвестиционной активности международных участников необходимо содействие продвижению экспортоориентированных проектов, создающих денежные потоки в твердой валюте;

- должны быть усовершенствованы условия для производителей и экспортеров высокотехнологичных товаров, активизирована мобилизация инвестиций, дающих мультипликативный эффект в конкурентоспособных секторах, принимая при этом во внимание ограничение притока иностранного капитала в сферы, обеспечивающие защиту национальной безопасности $[5,9,33]$;

- востребован механизм стимулирования инвестиционной активности и привлечения финансов для реализации в государствах членах ЕАЭС проектов. На их основе будут создаваться региональные производственнотехнологические цепочки добавленной стоимости, активизирующие сотрудничество промышленных предприятий;

для ускоренного продвижения перспективных проектов в приоритетных отраслях, следует разработать конкретные предложения для профильных инвесторов, стимулировать заинтересованность инвесторов в создании объектов индустриально-инновационной инфраструктуры по приоритетным проектам, компенсируя их расходы на строительство инфраструктуры; предполагается, что к 2027 году в приоритетных секторах с участием иностранных инвесторов будут заявлены 124 проекта с объемом финансирования 5 млрд. долл. Для заключения стратегических инвестиционных соглашений отобраны наиболее перспективные 25 проектов на 9,2 млрд. долл. [34];

- в условиях спада мировой экономики Казахстану необходима собственная позиция в принятии мер регулирования инвестиционного процесса. Предстоит координировать совместную работу, выстраивать взаимовыгодное сотрудничество с внешними партнерами, активизировать поиск каналов привлечения институционального капитала со стороны крупных международных финансовых организаций, находить новые форматы взаимодействия в таких приоритетных областях касающихся, к примеру, трансграничной транспортной инфраструктуры. Государственная политика должна быть нацелена на создание условий для взаимодействия зарубежных и местных предприятий по межотраслевым цепочкам.

Тема настоящего исследования далеко не исчерпана. Необходимы дальнейшие научные исследования, опирающиеся на реальную оценку инвестиционной привлекательности стран с переходной экономикой в условиях развертывания мировых и региональных интеграционных процессов с учетом разнообразных факторов, определяющих масштабы привлечения иностранного капитала.

\section{Список использованных источников}

1. Казахстан. Добровольный Национальный Обзор 2019: О реализации повестки дня до 2030 года в области устойчивого развития. АО «Институт экономических исследований». [Электронный pecypc]. URL: https:// https://economy.kz/documents/ OECD/obzor_nat_rus.pdf. Дата обращения 11.08.2021.

2. Приказ Министра по инвестициям и развитию Республики Казахстан от 21 мая 2018 года № 355 Об утверждении Правил приобретения недропользователями и их подрядчиками товаров, работ и услуг, используемых при проведении операций по добыче твердых полезных ископаемых (с изменениями и дополнениями по состоянию на 28.03.2020 г.). [Электронный ресурс]. URL: https:// online.zakon.kz/Document/?doc_id=38804705 (дата обращения 12.06.2021).

3. Кодекс «О недрах и недропользовании» Кодекс Республики Казахстан от 27 декабря 2017 года № 125-VI «О недрах и недропользовании» (с изменениями и дополнениями по состоянию на 09.03.2021 г.). [Электронный ресурc]. URL: https:// online.zakon.kz/document/?doc_id=31764592 (дата обращения 15.04.2021).

4. Изменение подходов в привлечении инвестиций, или как инвестиционная отрасль Казахстана адаптируется к вызовам пандемии [Электронный ресурс]. URL: https://primeminister. $\mathrm{kz} / \mathrm{ru} / \mathrm{news} /$ interviews/izmenenie-podhodov-vprivlechenii-investiciy-ili-kak-investicionnaya-otraslkazahstana-adaptiruetsya-k-vyzovam-pandemii-29244 (дата обращения 01.04.2021).

5. О проекте Закона Республики Казахстан «О промышленной политике. Постановление Правительства Республики Казахстна от 31 декабря 2020 года №957. [Электронный pecypc]. URL: https://adilet.zan.kz/rus/docs/ P2000000957 (дата обращения 07.04.2021).

6. Global Investment Competitiveness Report 2019-2020. [Электронный pecypc]. URL: https://openknowledge.worldbank.org/bitstream/ handle $/ 10986 / 33808 / 9781464815362$.pdf? sequence $=4$ (дата обращения 13.06.2021). 
7. Отчет «Всемирный доклад по инвестициям» ЮНКТАД (WIR 2021). [Электронный ресурс]. URL: https://unctad.org/system/files/official-document/ wir2021_en.pdf

8. Industrial Development Report 2020. Industrializing in the digital age Overview. Available from the Internet: https://www.unido .org/sites/ default/files/files/2019-11/UNIDO_IDR2020-English overview.pdf. [Электронный ресурс]. URL: https:// www.unido.org/resources-publications-flagshippublications-industrial-development-report-series/ $\underline{\mathrm{idr2020}}$ (дата обращения 11.08.2021).

9. Указ Президента Республики Казахстан от 15 февраля 2018 года № 636. «Об утверждении Национального плана развития Республики Казахстан до 2025 года и признании утратившими силу некоторых указов Президента Республики Казахстан (с изменениями по состоянию на 26.02.2021 г.)». [Электронный ресурс]. URL: https://online.zakon. kz/Document/?doc id=38490966 (дата обращения 03.06.2021).

10. Hanusch, H., Chakraborty, L. S., Khurana, S. (2017). Fiscal Policy, Economic Growth and Innovation: An Empirical Analysis of G-20 Countries, Levy Economics Institute Working Paper. No. 883. DOI: http://dx.doi.org/10.2139/ssrn.2924801

11. Кондратьев В., Кедрова Г., Попов В. (2021). Сервитизация промышленности: новая реальность. Мировая экономика и международные отношения. 65(8), 22-30. DOI: https://doi.org/10.20542/0131-22272021-65-8-22-30

12. Sako, M., Zylberberg, E. (2019). Firmlevel strategy and global value chains. In: S. Ponte, G. Gereffi, G. Raj-Reichert (eds.). Handbook on global value chains. Edward Elgar Publishing, 340-353. DOI: https://doi.org/10.4337/9781788113779.00030

13. Li, K., Kim, D. J., Lang, K. R., Kauffman, R. J., \& Naldi, M. (2020). How should we understand the digital economy in Asia? Critical assessment and research agenda. Electronic commerce research and applications, 44, 101004. DOI: https://doi.org/10.1016/j. elerap.2020.101004

14. Mateus, A., Martins, L. (2020). Building a mineral-based value chain in Europe: the balance between social acceptance and secure supply. Mineral economics. DOI: https://doi.org/10.1007/s13563-02000242-3. Early access: NOV 2020

15. Cai, D., Karasawa-Ohtashiro, Y. (2018). Greenfield, mergers and acquisition, or export? Regulating the entry multinational enterprises to a hostcountry market. International Review of Economics and Finance, 56, 397-407. DOI: https://doi.org/10.1016/j. iref.2017.11.008

16. Balta-Ozkan, N., Watson, T., Mocca, E. (2015). Spatially uneven development and low carbon transitions: insights from urban and regional planning. Energy Policy. 85, 500-510. DOI : 10.1016/j. enpol.2015.05.013

17. Klemm, A., Parys, S. (2012). Empirical evidence on the effects of tax incentives. International Tax and Public Finance, 19 (3), 393-423. DOI: 10.1007/ s10797-011-9194-8
18. Zolt, E. (2015). Paper for workshop on tax incentives and base protection. New York, 2324 April. https://www.un.org/esa/ffd/wp-content/ uploads/2015/04/2015TIBP PaperZolt.pdf

19. Behre Dolbear. (2014). Ranking of countries for mining investment: where 'not to Invest'. [Electronic source]. URL: Investment. Accessed 13 Aug 2014. http://www.dolbear.com/ literature 209687/2014 Ranking_of_Countries_for_Mining_ (date access 2.10.2015).

20. Campbell, B. (2012). Corporate social responsibility and development in Africa: redefining the roles and responsibilities of public and private actors in the mining sector. Resources Policy, 37(2), 138-143. DOI:10.1016/j.resourpol.2011.05.002

21. Jalilian, H., Kirkpatrick, C., Parker, D. (2007). The impact of regulation on economic growth in developing countries: a cross-country analysis. World Development, 35 (1), 87-103. DOI: 10.1016/j. worlddev.2006.09.005

22. El, Iysaouy L., El Amrani El Idrissi N., Tvaronavičienė, M., Lahbabi, M., Oumnad, A. (2019). Towards Energy Efficiency: Case of Morocco. Insights into Regional Development, 1 (3), 259-271. DOI: https://doi.org/10.9770/ird.2019.1.3(6).

23. Vivoda, V. (2017). Determinants of Foreign Direct Investment in the Mining Industry. In book: Mining in the Asia-Pacific: Risks, Challenges and Opportunities. Springer International Publishing AG. P. 19-33. DOI:10.1007/978-3-319-61395-6 2

24. Mackie, P., Worsley, T., Eliasson, J. (2014). Transport appraisal revisited. Research in Transportation Economics, 47, 3-18. DOI: https://doi. org/10.1016/j.retrec.2014.09.013

25. Нурланова Н.К. (2019). Смена парадигмы региональной политики в XXI веке (зарубежный опыт и рекомендации для Казахстана). Экономика: стратегия и практика, 1(14), 41-55.

26. Сколько иностранных инвестиций привлек Казахстан в 2020 году. Исследование. [Электронный pecypc]. URL: https://aqparat.info/ news/2021/01/25/9943054-skolko inostrannyh investicii privlek ka.html (дата обращения 01.11.2021).

27. Инвестиции как ключевой драйвер роста казахстанской экономики: новые предприятия, передовые технологии и создание рабочих мест. [Электронный pecypc]. URL: https://invest.gov. $\mathrm{kz} / \mathrm{ru} / \mathrm{media}$-center/press-releases/investitsii-kakklyuchevoy-drayver-rosta-kazakhstanskoy-ekonomikinovye-predpriyatiya-peredovye-tekh/ (дата обращения 05.10 .2021 ).

28. Анализ существующих международных транспортных коридоров, проходящих через территории государств-членов. Аналитический доклад, Департамент транспорта и инфраструктуры, Евразийская экономическая комиссия, Москва, 2019, 23 c.

29. Обзор инвестиционной привлекательности стран Центральной Азии. [Электронный pecypc]. URL: https://sk.kz/upload/iblock/d34/d34cfc 911970b45c9b695e392a7d250a.pdf (дата обращения 09.11.2021). 
30. OECD. Foreign Direct Investment Statistics: Data, Analysis and Forecasts. 2021. [Electronic source]. URL: http://www.oecd.org/investment/statistics.htm (date access: 13.04.2021).

31. Приоритетные отрасли, прямые иностранные инвестиции и новые подходы - какие меры по привлечению инвестиций принимаются в Казахстане. [Электронный ресурс]. URL: https:// www.primeminister.kz/ru/news/reviews/prioritetnyeotrasli-pryamye-inostrannye-investicii-i-novyepodhody-kakie-mery-po-privlecheniyu-investiciyprinimayutsya-v-kazahstane-3143955 (дата обращения 09.11.2021).

32. Под антикоррупционным сопровождением находится свыше 500 бизнес-проектов - Олжас Бектенов. [Электронный ресурс]. URL: https:// www.inform.kz/ru/pod-antikorrupcionnymsoprovozhdeniem-nahoditsya-svyshe-500-biznesproektov-olzhas-bektenov a3690569 (дата обращения 08.11.2021).

33. Kroll, H., \& Neuhausler, P. (2020). Recent Trends of Regional Development in China - Technological Portfolios and Economic Growth. Zeitschrift fur wirtschaftsgeographie, 64(1), 14-27. DOI: https://doi.org/10.1515/zfw-2018-0032.

34. Какие казахстанские проекты получат \$9 млрд. инвестиций. [Электронный ресурс]. URL: https://lsm.kz/strategicheskie-proekty-v-kazahstane (дата обращения 21.10.2021).

\section{References}

1. Kazahstan. Dobrovol'nyj Nacional'nyj Obzor 2019: O realizacii povestki dnya do 2030 goda v oblasti ustojchivogo razvitiya. AO «Institut ekonomicheskih issledovanij». [Elektronnyj resurs]. URL: https:// https://economy.kz/documents/OECD/obzor_nat_rus. pdf (date of access 11.08.2021).

2. Prikaz Ministra po investiciyam i razvitiyu Respubliki Kazahstan ot 21 maya 2018 goda № $355 \mathrm{Ob}$ utverzhdenii Pravil priobreteniya nedropol'zovatelyami i ih podryadchikami tovarov, rabot i uslug, ispol'zuemyh pri provedenii operacij po dobyche tverdyh poleznyh iskopaemyh (s izmeneniyami i dopolneniyami po sostoyaniyu na 28.03.2020 g.). [Elektronnyj resurs]. URL: https://online.zakon.kz/Document/?doc $\mathrm{id}=38804705$ (date of access 12.06.2021).

3. Kodeks «O nedrah i nedropol'zovanii» Kodeks Respubliki Kazahstan ot 27 dekabrya 2017 goda № 125 -VI «O nedrah i nedropol'zovanii» (s izmeneniyami i dopolneniyami po sostoyaniyu na 09.03.2021 g.). [Elektronnyj resurs]. URL: https://online.zakon. $\mathrm{kz} /$ document/?doc_id=31764592 (date of access 15.04.2021)

4. Izmenenie podhodov $\mathrm{v}$ privlechenii investicij, ili kak investicionnaya otrasl' Kazahstana adaptiruetsya $\mathrm{k}$ vyzovam pandemii [Elektronnyj resurs]. URL: https://primeminister.kz/ru/news/interviews/ izmenenie-podhodov-v-privlechenii-investiciy-ili-kakinvesticionnaya-otrasl-kazahstana-adaptiruetsya-kvyzovam-pandemii-29244.Date of access 01.04.2021.
5. On the draft Law of the Republic of Kazakhstan «On industrial policy. Resolution of the Government of the Republic of Kazakhstan No. 957 dated December 31, 2020. [Electronic resource]. URL: https://adilet.zan.kz/ rus/docs/P2000000957 (date of treatment 04/07/2021 ).

6. Global Investment Competitiveness Report 2019-2020. [Elektronnyj resurs]. URL: https://openknowledge.worldbank.org/bitstream/ handle $/ 10986 / 33808 / 9781464815362$.pdf? sequence $=4$ (date of access 13.06.2021).

7. Otchet «Vsemirnyj doklad po investiciyam» YuNKTAD (WIR 2021). [Elektronnyj resurs]. URL: https://unctad.org/system/files/official-document/ wir2021_en.pdf

8. Industrial Development Report 2020. Industrializing in the digital age Overview. Available from the Internet: https://www.unido .org/sites/ default/files/files/2019-11/UNIDO_IDR2020-English_ overview.pdf. [Elektronnyj resurs]. URL: https://www. unido.org/resources-publications-flagship-publicationsindustrial-development-report-series/idr2020 (date of access 11.08.2021)

9. Ukaz Prezidenta Respubliki Kazahstan ot 15 fevralya 2018 goda № 636. «Ob utverzhdenii Nacional'nogo plana razvitiya Respubliki Kazahstan do 2025 goda i priznanii utrativshimi silu nekotoryh ukazov Prezidenta Respubliki Kazahstan (s izmeneniyami po sostoyaniyu na 26.02.2021 g.)». [Elektronnyj resurs]. URL: https://online.zakon.kz/Document/?doc $\mathrm{id}=38490966$ (date of access 03.06.2021).

10. Hanusch, H., Chakraborty, L. S., Khurana, S. (2017). Fiscal Policy, Economic Growth and Innovation: An Empirical Analysis of G-20 Countries, Levy Economics Institute Working Paper. No. 883. DOI: http://dx.doi.org/10.2139/ssrn.2924801

11. Kondrat'ev, V., Kedrova, G., Popov ,V. (2021). Servitizaciya promyshlennosti: novaya real'nost'. Mirovaya ekonomika i mezhdunarodnye otnosheniya. 65(8), 22-30. DOI: https://doi.org/10.20542/0131-22272021-65-8-22-30 (in Russ.)

12. Sako, M., Zylberberg, E. (2019). Firmlevel strategy and global value chains. In: S. Ponte, G. Gereffi, G. Raj-Reichert (eds.). Handbook on global value chains. Edward Elgar Publishing, 340-353. DOI: https://doi.org/10.4337/9781788113779.00030

13. Li, K., Kim, D. J., Lang, K. R., Kauffman, R. J., \& Naldi, M. (2020). How should we understand the digital economy in Asia? Critical assessment and research agenda. Electronic commerce research and applications, 44, 101004. DOI: https://doi.org/10.1016/j. elerap.2020.101004

14. Mateus, A., Martins, L. (2020). Building a mineral-based value chain in Europe: the balance between social acceptance and secure supply. Mineral economics. DOI: https://doi.org/10.1007/s13563-02000242-3. Early access: NOV 2020

15. Cai, D., Karasawa-Ohtashiro, Y. (2018). Greenfield, mergers and acquisition, or export? Regulating the entry multinational enterprises to a hostcountry market. International Review of Economics and Finance, 56, 397-407. DOI: https://doi.org/10.1016/j. iref.2017.11.008

16. Balta-Ozkan, N., Watson, T., Mocca, E. (2015). Spatially uneven development and low 
carbon transitions: insights from urban and regional planning. Energy Policy. 85, 500-510. DOI : 10.1016/j. enpol.2015.05.013

17. Klemm, A., Parys, S. (2012). Empirical evidence on the effects of tax incentives. International Tax and Public Finance, 19 (3), 393-423. DOI: 10.1007/ s10797-011-9194-8

18. Zolt, E. (2015). Paper for workshop on tax incentives and base protection. New York, 2324 April. https://www.un.org/esa/ffd/wp-content/ uploads/2015/04/2015TIBP_PaperZolt.pdf

19. Behre Dolbear. (2014). Ranking of countries for mining investment: where ' 'not to Invest $\backslash$ '. [Electronic source]. URL: Investment. Accessed 13 Aug 2014. http://www.dolbear.com/_literature_209687/2014_ Ranking_of_Countries_for_Mining__(date access 2.10.2015).

20. Campbell, B. (2012). Corporate social responsibility and development in Africa: redefining the roles and responsibilities of public and private actors in the mining sector. Resources Policy, 37(2), 138-143. DOI:10.1016/j.resourpol.2011.05.002

21. Jalilian, H., Kirkpatrick, C., Parker, D. (2007). The impact of regulation on economic growth in developing countries: a cross-country analysis. World Development, 35 (1), 87-103. DOI: 10.1016/j. worlddev.2006.09.005

22. El Iysaouy L., El Amrani El Idrissi N., Tvaronavičienè, M., Lahbabi, M., Oumnad, A. (2019). Towards Energy Efficiency: Case of Morocco. Insights into Regional Development, 1 (3), 259-271. DOI: https://doi.org/10.9770/ird.2019.1.3(6).

23. Vivoda, V. (2017). Determinants of Foreign Direct Investment in the Mining Industry. In book: Mining in the Asia-Pacific: Risks, Challenges and Opportunities. Springer International Publishing AG. P. 19-33. DOI:10.1007/978-3-319-61395-6_2

24. Mackie, P., Worsley, T., Eliasson, J. (2014). Transport appraisal revisited. Research in Transportation Economics, 47, 3-18. DOI: https://doi. org/10.1016/j.retrec.2014.09.013

25. Nurlanova, N.K. (2019). Smena paradigmy regional'noj politiki v XXI veke (zarubezhnyj opyt i rekomendacii dlya Kazahstana). Ekonomika: strategiya i praktika, 1(14), 41-55 (in Russ.)

26.Skol'koinostrannyhinvesticijprivlekKazahstan v 2020 godu. Issledovanie. [Elektronnyj resurs]. URL: https://aqparat.info/news/2021/01/25/9943054-skolko inostrannyh_investicii_privlek_ka.html (date of access 01.11.2021).

27. Investicii kak klyuchevoj drajver rosta kazahstanskoj ekonomiki: novye predpriyatiya, peredovye tekhnologii i sozdanie rabochih mest. [Elektronnyj resurs]. URL: https://invest.gov.kz/ $\mathrm{ru} / \mathrm{media-center/press-releases/investitsii-kak-}$ klyuchevoy-drayver-rosta-kazakhstanskoy-ekonomikinovye-predpriyatiya-peredovye-tekh/ (date of access 05.10.2021).

28. Analiz sushchestvuyushchih mezhdunarodnyh transportnyh koridorov, prohodyashchih cherez territorii gosudarstv-chlenov. Analiticheskij doklad, Departament transporta i infrastruktury, Evrazijskaya ekonomicheskaya komissiya, Moskva, 2019, 23 s.
29. Obzor investicionnoj privlekatel'nosti stran Central'noj Azii. [Elektronnyj resurs]. URL: https://sk.kz/upload/iblock/d34/ d34cfc911970b45c9b695e392a7d250a.pdf (date of access 09.11.2021).

30. OECD. Foreign Direct Investment Statistics: Data, Analysis and Forecasts. 2021. [Electronic source]. URL: http://www.oecd.org/investment/statistics.htm (date access: 13.04.2021).

31. Prioritetnye otrasli, pryamye inostrannye investicii i novye podhody - kakie mery po privlecheniyu investicij prinimayutsya v Kazahstane. [Elektronnyj resurs]. URL: https://www.primeminister. $\mathrm{kz} / \mathrm{ru} /$ news/reviews/prioritetnye-otrasli-pryamyeinostrannye-investicii-i-novye-podhody-kakiemery-po-privlecheniyu-investiciy-prinimayutsya-vkazahstane-3143955 (date of access 09.11.2021).

32. Pod antikorrupcionnym soprovozhdeniem nahoditsya svyshe 500 biznes-proektov - Olzhas Bektenov. [Elektronnyj resurs]. URL: https:// www.inform.kz/ru/pod-antikorrupcionnymsoprovozhdeniem-nahoditsya-svyshe-500-biznesproektov-olzhas-bektenov_a3690569 (date of access 08.11.2021).

33. Kroll, H., \& Neuhausler, P. (2020). Recent Trends of Regional Development in China - Technological Portfolios and Economic Growth. Zeitschrift fur wirtschaftsgeographie, 64(1), 14-27. DOI: https://doi.org/10.1515/zfw-2018-0032.

34. Kakie kazahstanskie proekty poluchat $\$ 9$ mlrd. investicij. [Elektronnyj resurs]. URL: https://lsm. $\mathrm{kz} /$ strategicheskie-proekty-v-kazahstane (date of access 21.10.2021). 


\section{Information about the authors}

Gulnara M. Aubakirova- Doctor of Economics, Professor of the Department of Economics and Enterprise Management, Karaganda Technical University, Republic of Kazakhstan, e-mail: rendykar@gmail.com. ORCID ID: https: //orcid.org/0000-0003-0337-1539

Saule K. Mazhitova- Candidate of Economic Sciences, Associate Professor, Head of the Department of Marketing and Logistics, Karaganda University of Kazpotrebsoyuz, Republic of Kazakhstan, e-mail: skm19@mail.ru. ORCID ID: https: //orcid.org/0000-0003-3986-6066

* Farida M. Isatayeva- Correspondent author, PhD Doctors, Karagandy Tekhniki Universitetsinin Geology Zhene Paidaly Kazbalardy Barlau Chairsyny Megherushisi, Kazakhstan Respubliki, e-mail: isataeva.farida@gmail.com. ORCID ID: https://orcid.org/0000-0001-6208-3292

Aigerim E. Tomashinova - Master Economics, Senior Lecturer of the Department of Marketing and Logistics, Karaganda University of Kazpotrebsoyuz, Republic of Kazakhstan, e-mail: shodyrova_a_e@mail.ru

\section{Авторлар туралы мәліметтер}

Аубакирова Гульнара Муслимовна - экономика ғылымдарының докторы, Қарағанды техникалық университетінің «Экономика және кәсіпорынды басқару» кафедрасының профессоры, Қазақстан Республикасы, e-mail: rendykar@gmail.com. ORCID ID: https: //orcid.org/0000-0003-0337-1539

Мажитова Сәуле Қалиевна - э.ғ.к., доцент, Қазтұтынуодағы Қарағанды университетінің маркетинг және логистика кафедрасының меңгерушісі, Қазақстан Республикасы, e-mail: skm19@mail.ru. ORCID ID: https: // orcid.org/0000-0003-3986-6066

* Исатаева Фарида Мұратқызы - корреспондент автор, PhD докторы, Қарағанды техникалық университетінің геология және пайдалы қазбаларды барлау кафедрасының меңгерушісі, Қазақстан Республикасы, е-таil: adambekova_farid@mail.ru. ORCID ID:_https://orcid.org/0000-0001-6208-3292

Томашинова Айгерім Еркенқызы - магистр Экономика, Қазтұтынуодағы Қарағанды университетінің маркетинг және логистика кафедрасының аға оқытушысы, Қазақстан Республикасы, e-mail: shodyrova_a_e@ mail.ru

\section{Сведения об авторах}

Аубакирова Гульнара Муслимовна - доктор экономических наук, профессор кафедры «Экономика и менеджмент предприятия», Карагандинский технический университет, Республика Казахстан, е-таil: rendykar@gmail.com. ORCID ID: https://orcid.org/0000-0003-0337-1539

Мажитова Сауле Калиевна - кандидат экономических наук, доцент, заведующий кафедрой «Маркетинга и логистики», Карагандинский университет Казпотребсоюза, Республика Казахстан, e-mail: skm19@mail.ru. ORCID ID: https://orcid.org/0000-0003-3986-6066

* Исатаева Фарида Муратовна - корреспондент автор, доктор $\mathrm{PhD}$, заведующий кафедрой «Геология и разведка месторождений полезных ископаемых», Карагандинский технический университет, Республика Казахстан, e-mail: isataeva.farida@gmail.com. ORCID ID: https://orcid.org/0000-0001-6208-3292

Томашинова Айгерим Еркеновна, магистр экономических наук, старший преподаватель кафедры «Маркетинга и логистики», Карагандинский университет Казпотребсоюза, Республика Казахстан, е-таil: shodyrova_a_e@mail.ru 